\title{
PETIS 法による植物試料中の水分動態のリアルタイム計測
}

\author{
横田 はる美 ${ }^{\circ}$ (東大院), 古川 純(東大院), 田野井 慶太朗(東大院) \\ 上岡 志ほり(東大院)，松橋 信平(原研高崎)，石岡典子(原研高崎) \\ 渡辺 智(原研高崎), 内田 博(浜松ホトニクス), 辻 淳憲(浜松ホトニクス) \\ 伊藤 岳人(原研高崎), 水庭 千鶴子(原研高崎), 長 明彦(原研高崎) \\ 関根 俊明(原研高崎), 橋本 昭司(原研高崎), 中西 友子(東大院)
}

\section{Real-Time Analysis of Water Movement in Plant Sample}

\section{by PETIS (Positron Emitting Tracer Imaging System)}

H.Yokota , J.Furukawa , K.Tanoi, S.Ueoka , S.Matsuzaki, N.S.Ishioka , S.Watanabe , H.Uchida , A.Tsuji , T.Ito , T.Mizuniwa , A.Osa, T.Sekine, S.Hashimoto and T.M.Nakanishi

\begin{abstract}
To know the effect of drought stress on two cultivars of cowpea, drought tolerant (DT) and drought sensitive (DS), and to estimate vanadium treatment on plant activity, we performed real time ${ }^{18} \mathrm{~F}$ labeled water uptake measurement by PETIS. Fluoride-18 was produced by bombarding a cubic ice target with $50 \mathrm{MeV}$ protones using TIARA AVF cyclotron. Then ${ }^{18} \mathrm{~F}$ labeled water was applied to investigate water movement in a cowpea plant. Real time water uptake manner could be monitored by PETIS. After the analysis by PETIS, we also measured the distribution of ${ }^{18} \mathrm{~F}$ in a whole plant by BAS. When a cowpea plant was treated with drought stress, there was a difference in water uptake manner between DT and DS cultivar. When a cowpea plant was treated with $\mathrm{V}$ for 20 hours before the water uptake experiment, the total amount of ${ }^{18} \mathrm{~F}$ labeled water absorption was found to be drastically decreased.
\end{abstract}

Keywords : positron emitting nuclide, water movement, plant

\section{1.はじめに}

植物生体内の水の挙動は、研究手法が未発達であるこ とからこれまでのところ不明な点が数多く残っている。 当研究室では、 ${ }^{18} \mathrm{~F}$ 標識水を用いて耐乾性植物ササゲに おける水の挙動を調べてきた。ササゲ(Vigna unguiculata (L.) Walp.)には、乾燥耐性種の cv.11979 と乾燥感受性種の cv.9357 がある。乾燥耐性種のササゲ は初葉節と第一本葉節間の肥大部分が水分貯蔵の役割を 果たしており、乾燥処理によりこの貯水組織から優先的 に水分が他組織へ移行する ${ }^{1}$ 。一方、乾燥感受性種のサ サゲは茎も細く、貯蔵組織らしい肥大した茎が確認でき
ない。高崎原子力研究所の PETIS (Positron Emission Tracer Imaging System）は、植物を生きたままの状態 で測定・観察することが可能である。そこで、植物にお けるリアルタイムの水分吸収動態を調べるため、ササゲ の乾燥耐性種と感受性種を対象に乾燥処理後の水分吸収 活性を比較検討することにした。また、バナジウム(V) による水分吸収の阻害についても検討した。

\section{2. 材料および方法}

Fig.1 に示すようなポジトロンイメージング計測は、 トレーサーとして投与した核種から放出されるポジトロ ンが近傍の電子と結合して消滅し、反対方向に一対の 
横田はる美，古川純，田野井慶太朗，上岡志ほり，松橋信平，石岡典子，渡辺 智，内田博， 辻 淳憲，伊藤岳人，水庭千鶴子，長 明彦，関根俊明，橋本正司，中西友子

\section{Overview of PETIS}

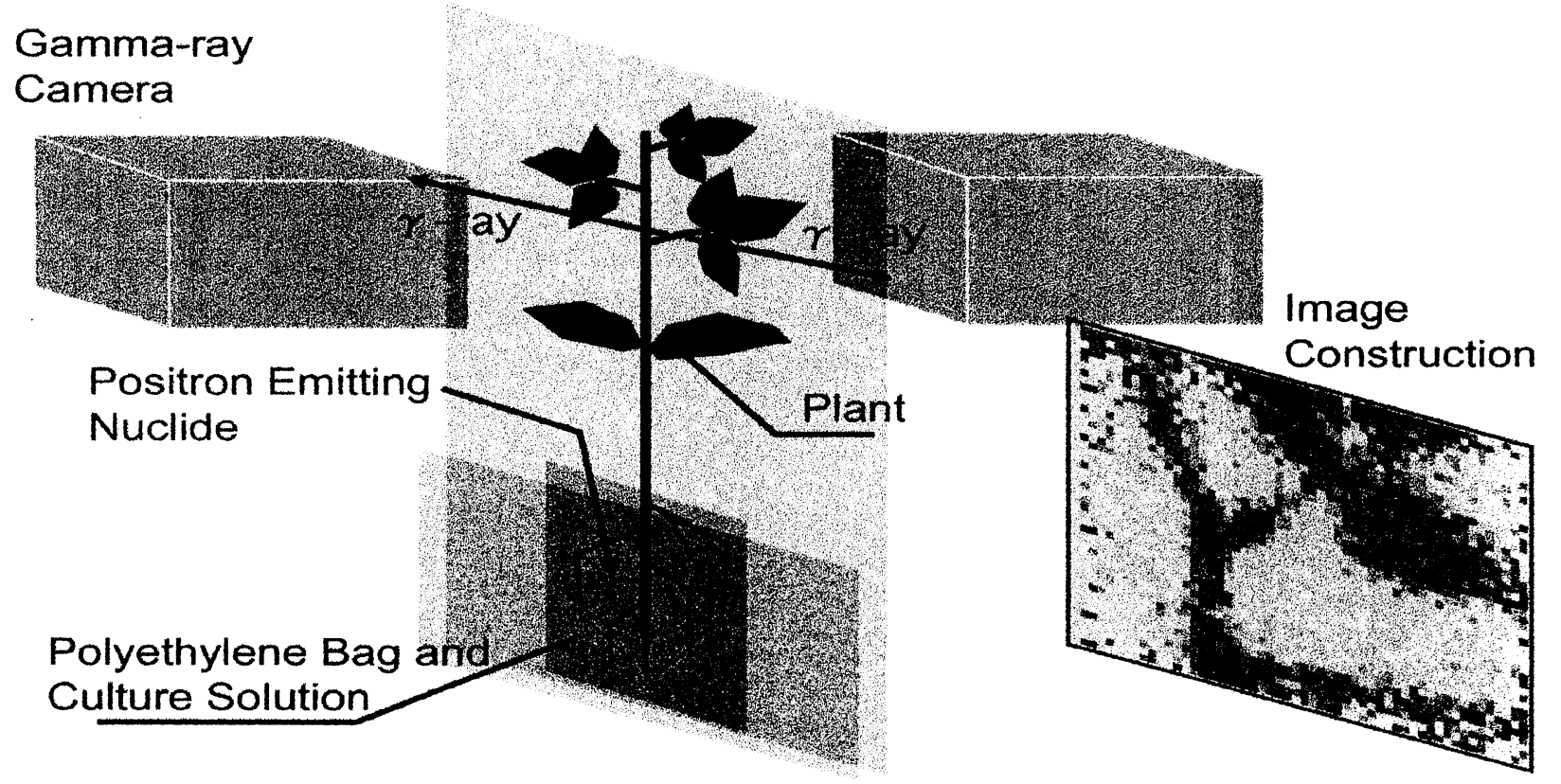

Fig. 1

線(511 keV)を放出することを利用した計測手法である。 対向配置した $\gamma$ 線二次元入射位置検出器（以後、植物用 ポジトロンカメラと呼ぶ）で同時計測することにより、 同一の消滅事象のみによる $\gamma$ 線を選択的に検出しており、 ポジトロンの消滅位置は、それぞれの検出器での $\gamma$ 線検 出位置を結ぶ線上と試料の設置面の交点となる。現時点 ではカメラの撮影可能な範囲は大視野型が $150 \times 48 \mathrm{~m}$ $\mathrm{m}$ で、小視野型が $50 \mathrm{~mm} \times 48 \mathrm{~mm}$ であり、空間分解能 は約 $2.4 \mathrm{~mm}$ である。また、カメラの視野は植物体全体 をカバーすることができないため、多点式検出器を併用 して視野の不足を補っている。撮影は地上部の茎および 葉を中心にカメラを、根と初葉の間の茎に多点式検出器 を設置して行なった。画像は Fig.1 の右下のようなも のとして得られる。測定されたデータはコンピュータに 蓄積され、計測後に任意の点における時系列グラフを用 いた解析を行うことができる。

${ }^{18} \mathrm{~F}$ 標識水は原子力研究所高崎研究所の AVF サイク ロトロンで製造された ${ }^{2)}$ 。超純水をターゲットにした ${ }^{16} \mathrm{O}(\alpha, \mathrm{pn}){ }^{18} \mathrm{~F}$ 反応を用いて調製し、不純物は陽イオン 交換樹脂を用いて取り除いた。製造は高崎原子力研究所 アイソトープ部のスタッフによって行われた。

供試植物として用いた二種類のササゲは、湿らせたバ 一ミキュライト中で発芽させ、発芽後 $2 \sim 3$ 日で水耕に 移し、3 週間ファイトトロン内で育成した植物から同程 度に成長しているものを選んでサンプルとした。育成条 件は温度 $25{ }^{\circ} \mathrm{C}$ 、湿度 $70 \%$ 、照度 20000 lux であり、 育成用の水耕液には MGRL 完全水耕液を用い ${ }^{3)}$ 、毎週 交換した。選択されたサンプルは 2 枚のアクリル板に挟 まれたガラス管付きのビニール袋に根が水耕液に浸され
た状態で設置され、対向して配置された一対の植物用ポ ジトロンカメラの中央に撮影部位を固定された。乾燥処 理区は乾燥酎性種・感受性種共に測定開始の 1 時間前に 根が浸してあった水耕液を抜き取り、ドラフトフード内 に放置した後に撮影位置に固定した。ガラス管と ${ }^{18} \mathrm{~F}$ 標 識水の入ったバイアルを連結用チューブでつないだ後、 シリンジを用いて密閉バイアル中の溶液に圧力をかける ことにより水耕液の除去と ${ }^{18} \mathrm{~F}$ 標識水の輸送を行った。 ${ }^{18} \mathrm{~F}$ 標識水が根の入っている袋に到達した時点で測定を 開始し、3 分間標識水を吸収させた後、先と同様の方法 で標識水とイオン交換水を入れ替えた。 $\mathrm{V}$ 処理は乾燥感 受性種に、測定開始の 6、20 時間前に $500 \mu \mathrm{M}$ のバナ ジン酸を処理し、上記のように ${ }^{18} \mathrm{~F}$ 標識水の輸送を行っ た。 $\mathrm{V}$ 処理では標準水とイオン交換水の入れ替えは行な わなかった。それぞれ 30 分間測定を行ない、終了後は ラジオルミノグラフィ(FUJIFILM, MacBAS-1500)に よる地上部の ${ }^{18} \mathrm{~F}$ 分布の撮影を行った。

\section{3. 結果および考察}

Fig.2 は PETIS で得られた乾燥耐性種の画像である。 コントロール区と乾燥処理区で吸収に大きな差は見られ なかった。また、 ${ }^{18} \mathrm{~F}$ をパルス的に投与したので、時間 と共に茎の下部の ${ }^{18} \mathrm{~F}$ は抜けていくことが期待されたが、 完全になくなることはなく、30 分経過した段階でもま だ残っていた。これは $\mathrm{F}^{-}$イオンが導管の壁に吸着する もしくは導管から周囲の組織に浸出していることを示し ている。この連続画像から定点の $\gamma$ 線放出量をトレース したグラフでは，画像では見えにくかった茎の部分での パルスがピークで示されており、茎を通過した ${ }^{18} \mathrm{~F}$ が葉 


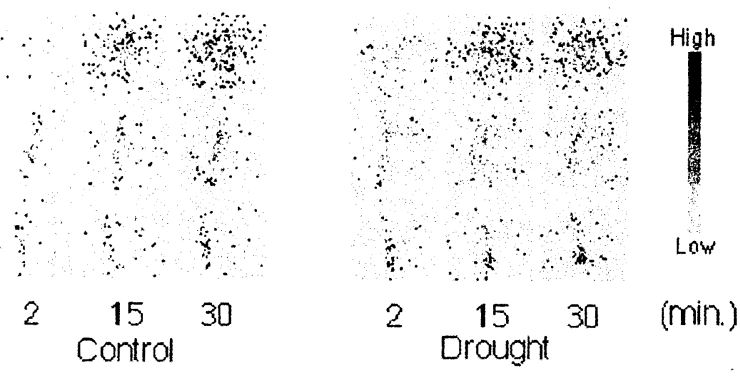

Fig.2

に蓄積されていることもわかつた。

Fig.3 は多点式検出器を用いて計測した結果である。 多点式検出器は検出感度が高く、それを根と初葉の間の 茎に設置したデータであり、根からの移動をよりはっき りと示すと考えられる。上図が乾燥耐性種のグラフであ り、下図が乾燥感受性種のものである。乾燥耐性種では コントロール区、乾燥処理区共にピークが見られ、乾燥 処理区の方がコントロール区に比べピークが高く、 ${ }^{18} \mathrm{~F}$ の吸収量が多いことが示されている。ピークの高さに差 が現れたことについては後に考察する。感受性種では乾 燥処理を施した後はピークが明らかでなくなっており、 処理が吸水にダメージを与えていることが示された。ま
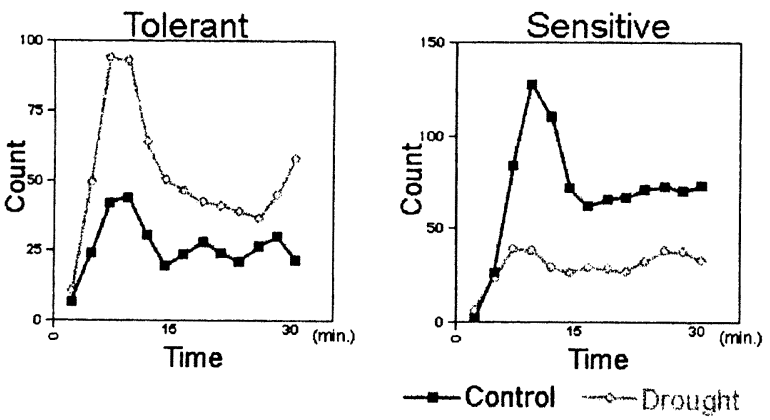

Fig. 3

た、乾燥耐性種よりもコントロール区でピークが高く現 れており、低負荷の状態においては感受性種のほうがコ ントロール区に比べ吸収能力が強い可能性も示唆された。

Fig.4 は乾燥耐性種・感受性種それぞれのコントロー ル区と乾燥処理区を PETIS による計測が終了した後に BAS で撮影したものである。ここでも耐性種は乾燥処 理後にコントロール区とほぼ同様な吸収を見せ、また主 に葉に吸い上げていることが示されている。それに対し、 感受性種はコントロール区で特徵的な像が得られ、茎に 多く吸収されていることが示されたが、乾燥処理を施し た後は茎への吸着も見られなくなり葉への蓄積も減少し ていた。この感受性区で見られた茎への吸着が乾燥耐性 能と関わっているかどうかは不明であるが、吸収した水 を蒸散流によって葉まで吸い上げるだけでなく、茎の組
織にも分配していることが示されている。

6、20 時間バナジン酸を前処理した乾燥感受性種の ササゲについても同様に計測を行なった。20 時間処理 をすると、水分吸収量が大きく減少していた。

このように、植物中での分布などでは ${ }^{18} \mathrm{~F}$ 標識水は植 物の水分吸収動態をリアルタイムに計測するのに有効な 手段であると考えられる。今回得られた乾燥耐性種・感 受性種の乾燥ストレスに対する異なった反応が初葉節と 第一本葉節間にある貯水組織によるものかどうかはわか らなかったが、BAS 像から主に葉に ${ }^{18} \mathrm{~F}$ が吸い上げら れていたこと、乾燥処理により両種ともかなりしおれて 見えること、また耐性種で導管内の水不足に由来すると 考えられる吸い上げ速度の上昇が見られたことから、肥 大組織の見られない乾燥感受性種で導管内の水が耐性種 以上に不足し、通導組織における水の連続性が途切れて 蒸散流に乗せて水分を吸収することが困難になったため ではないかと考えられる。

以上のように PETIS を用いることにより植物中での 水の移動を時間的な側面から検討することが可能であっ た。今後、このようにして明らかにされた水の移動が植 物中における情報伝達を解明する一端となることを期待 する。

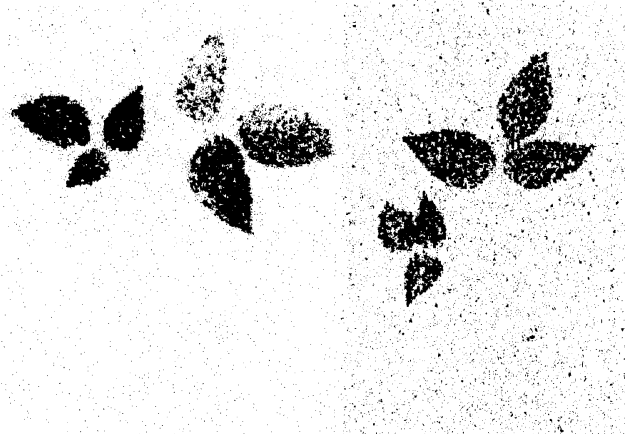

A $\quad$ B

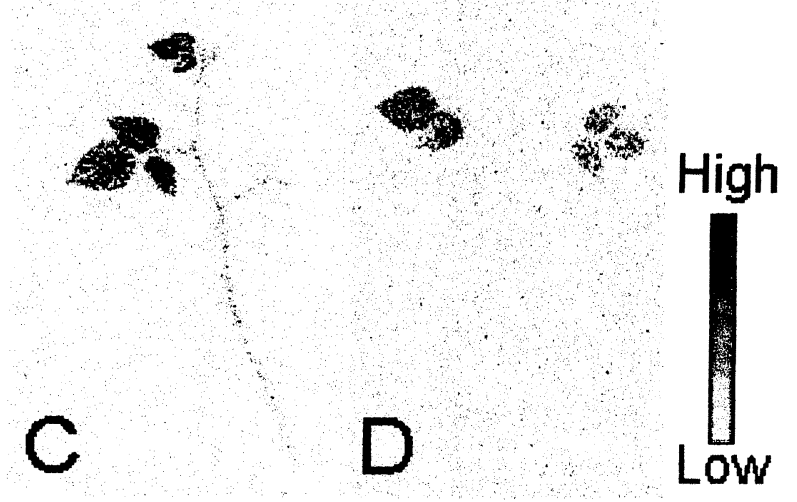

Fig. 4
A : Tolerant-Control
B : Tolerant-Drought
C : Sensitive-Control
C : Sensitive-Drought 


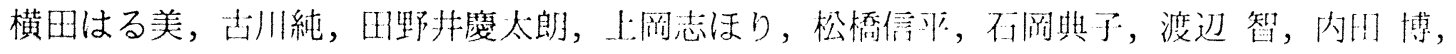

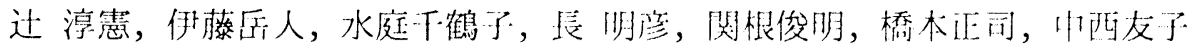

\section{参考文献}

1) T.M.Nakanishi, K.Don-Jin, T.Kitamura, R.Ishii,

M.Matsubayashi : Identification of Water Storage

Tissue in the Stem of Cowpea Plant(Vigna unguliculata Walp.) by Neutron Radiography, J. of Radioanal. Nucl. Chemi. Vol.242, No.2 (1999) pp.353-359

2) N.S.Ishioka, H.Matsuoka, S.Watanabe, A.Osa,

M.Koizumi, T.Kume, S.Matsuhashi, T.Fujimura, A.Tuji,

H.Uchida, T.Sekine,

Production of positron emitters and application of their labeled compounds to plant studies

J. Radioanal. Nucl. Chem., 239 (1999) 417-421

3) T.Fujiwara, M.Y.Hirai, M.Chino, Y.Komeda, S.Naito

Effects of Sulfur Nutrition on Expression of the Soybean

Seed Storage Protein Genes in Transgenic Petunia

Plant Physiol. 991992 263-268 